\title{
EVALUASI PERTUMBUHAN LIMA STRAIN IKAN NILA PADA MEDIA BERSALINITAS
}

\author{
M. H. Fariduddin Ath-thar ${ }^{1}$, Dadang Ariyanto ${ }^{2}$ dan Rudhy Gustiano ${ }^{1^{*}}$ \\ ${ }^{1}$ Balai Riset Perikanan Budidaya Air Tawar, J1. Sempur No. 1, Bogor 16154 \\ *email : rgustiano@yahoo.com \\ ${ }^{2}$ Sekolah Tinggi Perikanan, Jurusan Budidaya, Pasar Minggu, Jakarta
}

\begin{abstract}
Evaluation of Salinity Tolerance on Five Strains of Nile Tilapia (Oreochromis niloticus). By. M. H. Fariduddin Ath-thar, Dadang Ariyanto and Rudhy Gustiano
\end{abstract}

\begin{abstract}
The objective of the study was to evaluate the salinity tolerance of five strains of nile tilapia, BEST (Bogor Enhanced Strain Tilapia), Lokal Kuningan (LK), Red NIFI $(R N)$, nila merah (NM) dan nila hitam (NH), in 15 ppt saline water. Initial size of fish examined was 3-5 cm, reared in $100 \times 40 \times 60 \mathrm{~cm}$ aquaria with density of 25 fish per aquarium. Each strain had 4 replications. During experiment fish were fed with commercial pellet, $5 \%$ of body weigth per day. Observation was done on standard length, body weight, biomass, and survival rate every 10 days for 1 month. Growth of length and body weight showed no differences among strains. For biomass, BEST strain except with RN was significantly different $(P<0.01)$ compare to NH, NM and LK. On the other hand, RN was not significantly different with $N H$, but significantly different with $L K$ and NM. For survival rate, BEST strain had the highest percentage among others and significantly different than $L K, N M$ and $N H$. RN was also significantly different than LK, NM, and NH. The last three strains were not significant different among them.
\end{abstract}

Keywords : Strain, oreochromis, salinity, growth

\section{ABSTRAK}

Banyaknya lahan tambak yang tidak dioperasikan lagi (idle) merupakan lahan tidur yang perlu dioptimalkan Penelitian yang dilakukan bertujuan untuk melakukan evaluasi pertumbuhan benih ikan nila strain BEST (Bogor Enhanced Strain Tilapia), lokal Kuningan, Red NIFI, nila merah dan nila hitam di masyarakat pada media bersalinitas 15 ppt. Ikan uji yang digunakan berukuran 3-5 cm dipelihara dalam akuarium ukuran $100 \times 40 \times 60 \mathrm{~cm}$ dengan kepadatan 25 ekor menggunakan 4 ulangan untuk masing-masing strain. Selama pemeliharaan, ikan diberi pakan komersial (pellet) sebanyak 5\% per hari dari bobot tubuh. Pengamatan panjang baku, bobot tubuh, biomasa dan sintasan dilakukan setiap 10 hari sekali selama masa pemeliharaan. Pengamatan pertumbuhan panjang dan bobot tubuh memperlihatkan bahwa kelima strain yang diuji tidak memperlihatkan adanya perbedaan pertumbuhan panjang dan bobot. Untuk biomassa, BEST memberikan hasil yang terbaik dan berbeda nyata dengan NH, NM dan LK namun tidak berbeda nyata dengan RN. Sedangkan RN tidak berbeda nyata dengan NH $(\mathrm{P}<0,01)$ tetapi berbeda nyata dengan LK dan NM. Untuk pengamatan sintasan, ikan nila BEST mempunyai nilai yang terbaik dan berbeda sangat nyata $(\mathrm{P}<0,01)$ dibandingkan dengan $\mathrm{LK}$, NM dan NH tetapi tidak berbeda nyata dengan RN. Demikian pula untuk RN yang berbeda nyata dengan LK, NM dan NH. Sedangkan untuk ketiga strain lainnya (LK, $\mathrm{NM}$ dan $\mathrm{NH}$ ) tidak memberikan perbedaan nyata satu sama lain.

Kata kunci : Strain, oreochromis, salinitas, pertumbuhan

\section{PENDAHULUAN}

Kini paradigma ketahanan pangan telah bergeser dari sekedar kenyang kepada kualitas pangan yang dikonsumsi. Ikan sebagai sumber protein hewani telah menjadi salah satu target pembangunan nasional. Pada tahun 2007 ditetapkan $2,5 \mathrm{~kg} /$ orang/kapita/ tahun, dan pada tahun 2008 menjadi 2,8 kg/orang/kapita/tahun. Dengan demikian kebutuhan pangan dari perikanan terus meningkat. Yang menjadi masalah adalah dapat tidaknya kenaikan akan konsumsi ikan tersebut dipenuhi. Berdasarkan sumber perikanan tangkap (penangkapan) nampaknya akan sulit dicapai karena kenaikan dari perikanan tangkap hanya mampu dipacu 4 persen/ tahun untuk mempertimbangkan kelestarian. Dengan demikian harapan pemenuhan protein sumber ikan hanya mengandalkan pasokan dari budidaya. Hasil perikanan budidaya ditargetkan naik 38 persen per tahun. Hal itu dikarenakan target perikanan harus meningkat 20 persen per tahun. Berkaitan dengan ketahanan pangan yang bersumber dari ikan, dapat menggantikan 15 persen ketergantungan masyarakat Indonesia terhadap unggas (ayam dan telur) sudah merupakan kesuksesan tersendiri. Dengan adanya masalah flu burung dan penyakit pada hewan (anthrax, sapi gila dan flu babi), 
peranan perikanan diharapkan lebih besar diantaranya melalui ikan nila, lele dan patin.

Potensi sumberdaya perikanan budidaya secara nasional diperkirakan sebesar 15,59 juta $\mathrm{Ha}$ yang terdiri atas potensi air tawar sebesar 2,23 juta $\mathrm{Ha}$, air payau 1,22 juta $\mathrm{Ha}$ dan budidaya laut 12,14 juta Ha. Sedangkan pemanfaatannya hingga saat ini masing-masing baru mencapai 10,1 persen untuk budidaya air tawar, 40 persen budidaya air payau dan 0,01 persen untuk budidaya laut. Mengingat pemanfaatan potensi perikanan budidaya yang masih demikian rendah maka diperlukan langkahlangkah konkrit mendorong peningkatan produksi ikan yang permintaan pasarnya sangat besar baik untuk konsumsi dalam negeri maupun luar negeri. Banyaknya lahan tambak yang tidak dioperasikan lagi (idle) merupakan lahan tidur yang perlu dioptimalkan.

Peranan ikan sebagai sumber pangan yang semakin meningkat menuntut peningkatan produksi perikanan yang dapat dilakukan dengan optimalisasi lahan dan penggunaan strain unggul. Ketersediaan perairan payau membutuhkan jenis dan strain yang dapat dibudidayakan di perairan tersebut. Namun demikian, belum tentu semua jenis varietas unggulan toleran terhadap salinitas tinggi. Gustiano et al. (2005) melaporkan bahwa keunggulan suatu strain ikan nila di Indonesia berkaitan dengan lingkungan yang sesuai dimana strain tersebut dapat mengekspresikan keunggulan genetiknya secara optimal. Untuk strain yang memiliki keunggulan yang sangat besar dan mempunyai toleransi lingkungan yang luas potensi sifat unggul tetap muncul di lingkungan berbeda meskipun tidak optimal (Matricia et al., 1989; Kusdiarti et al., 2008; Winarlin et al., 2008) atau sistem pemeliharaan berbeda (Huwoyon dan Gustiano, 2008; Arifin et al., 2009). Sedangkan hasil-hasil riset sejenis di luar Indonesia telah dilaporkan di Filipina oleh Romana and Doyle (1992), Kuwait oleh Ridha (2008) dan di Afrika oleh Maluwa and Gjerde (2006). Penelitian yang dilakukan bertujuan untuk melakukan evaluasi pertumbuhan benih ikan nila berbagai strain/populasi dalam media bersalinitas.

\section{BAHAN DAN METODA}

Ikan nila yang digunakan dalam penelitian ini adalah strain BEST, lokal Kuningan (LK), Red NIFI (RN), nila merah (NM) dan nila hitam (NH) di masyarakat. Ikan uji yang digunakan berukuran 3-5 $\mathrm{cm}$. Ikan dipelihara dalam akuarium ukuran $100 \mathrm{x}$ 40 x $60 \mathrm{~cm}$ dengan kepadatan 25 ekor tiap ulangan sebanyak 4 ulangan untuk masing-masing strain dan diberikan aerasi. Air bersalinitas dibuat dengan cara menambahkan garam tambak dengan air tawar sehingga mencapai $15 \mathrm{ppt}$ hasil peneraaan menggunakan "refraktometer". Selama pemeliharaan, ikan diberi pakan komersial (pellet) sebanyak 5\% per hari dari bobot tubuh. Pengamatan pertumbuhan panjang baku dan bobot tubuh dilakukan setiap 10 hari sekali selama 30 hari masa pemeliharaan dengan cara mengukur panjang dan menimbang bobot semua ikan dalam setiap ulangan/akuarium. Untuk sintasan dilakukan penghitungan secara akumulatif setiap 10 hari. Sedangkan biomass dilakukan dengan cara menimbang total ikan yang ada di dalam akuarium. Analisa data dilakukan dengan analisa sidik ragam yang diteruskan dengan Duncan test untuk mengetahui tingkat perbedaan antar perlakuan yang diamati.

\section{HASIL DAN PEMBAHASAN}

Hasil pengamatan yang diperoleh disajikan pada Tabel 1 dan 2. Tabel tersebut merupakan pengamatan hingga hari ke 30 . Pada tabel tersebut terlihat beberapa indikasi yang menunjukkan perbedaan dari strain-strain yang diamati.

Untuk data pengamatan pertumbuhan panjang tubuh, nampak bahwa kelima strain yang diuji tidak memperlihatkan adanya perbedaan pertumbuhan panjang. Untuk pertumbuhan bobot, empat dari lima strain yang diuji (BEST, Red Nifi, Merah dan Hitam) memberikan pertumbuhan yang tidak berbeda nyata. Namun strain-strain tersebut lebih baik dan berbeda nyata $(\mathrm{P}<0,01)$ terhadap LK. Sedangkan untuk sintasan ikan nila BEST nilai yang terbaik dan berbeda sangat nyata $(\mathrm{P}<0,01)$ dibandingkan dengan keempat strain lainnya. Untuk pengamatan biomassa, data yang dianalisa menggunakan ulangan yang memiliki sintasan di atas $60 \%$ untuk menghindari bias nilai yang dipengaruhi oleh karena adanya perbedaan padat tebar per akuarium. Mengacu Tabel 2, Pengamatan pertumbuhan panjang dan bobot tubuh memperlihatkan bahwa kelima strain yang diuji tidak memperlihatkan adanya perbedaan pertumbuhan panjang dan bobot. Sedangkan untuk biomassa BEST memberikan hasil yang terbaik dan berbeda nyata dengan $\mathrm{NH}$, NM dan LK namun tidak berbeda nyata dengan RN. Sedangkan RN tidak berbeda nyata dengan $\mathrm{NH}(\mathrm{P}<0,01)$ tetapi berbeda nyata dengan LK dan NM. Penelitian terdahulu dalam lingkungan air tawar (salinitas 0) dilaporkan bahwa ikan nila BEST lebih unggul dibandingkan dengan Red NIFI baik pada sistem pemeliharaan secara bersama (Huwoyon dan 
Gustiano, 2008) maupun secara terpisah (Arifin et al., 2009). Untuk pengamatan sintasan, ikan nila BEST mempunyai nilai yang terbaik dan berbeda sangat nyata $(\mathrm{P}<0,01)$ dibandingkan dengan $\mathrm{LK}$, $\mathrm{NM}$ dan $\mathrm{NH}$ tetapi tidak berbeda nyata dengan RN.
Demikian pula untuk RN yang berbeda nyata dengan LK, NM dan NH. Sedangkan untuk ketiga strain lainnya (LK, NM dan NH) tidak memberikan perbedaan nyata satu sama lain.

Tabel 1. Data Pengamatan Pertambahan Panjang, Bobot Tubuh dan Sintasan Selama 30 Hari Pengamatan

\begin{tabular}{|c|c|c|c|c|c|c|c|c|c|c|c|c|}
\hline \multirow{2}{*}{$\begin{array}{l}\text { Strain/ } \\
\text { populasi }\end{array}$} & \multicolumn{4}{|c|}{ Panjang } & \multicolumn{4}{|c|}{ Bobot } & \multicolumn{4}{|c|}{ Sintasan } \\
\hline & T0 & $\mathrm{T} 1$ & $\mathrm{~T} 2$ & T3 & T0 & T1 & $\mathrm{T} 2$ & T3 & T0 & $\mathrm{T} 1$ & $\mathrm{~T} 2$ & $\mathrm{~T}_{3}$ \\
\hline BEST & $\begin{array}{l}4,5 \quad \pm \\
0,09\end{array}$ & $\begin{array}{l}5,3 \pm \\
0,05\end{array}$ & $\begin{array}{ll}5,6 \quad \pm \\
0,07\end{array}$ & $\begin{array}{l}5,8 \pm \\
0,05\end{array}$ & $\begin{array}{l}3,4 \quad \pm \\
0,19\end{array}$ & $\begin{array}{l}5,8 \pm \\
0,15\end{array}$ & $\begin{array}{l}6,9 \pm \\
0,31\end{array}$ & $\begin{array}{l}7,3 \pm \\
0,18\end{array}$ & $\begin{array}{l}100,0 \pm \\
0,00\end{array}$ & $\begin{array}{l}100,0 \pm \\
0,00\end{array}$ & $\begin{array}{l}99,0 \pm \\
2,00\end{array}$ & $\begin{array}{l}94,0 \pm \\
4,00\end{array}$ \\
\hline Lokal Kuningan & $\begin{array}{l}3,5 \pm \\
0,26\end{array}$ & $\begin{array}{l}4,3 \pm \\
0,2\end{array}$ & $\begin{array}{l}5,6 \pm \\
0,44\end{array}$ & $\begin{array}{l}4,5 \pm \\
0,20\end{array}$ & $\begin{array}{l}1,8 \pm \\
0,42\end{array}$ & $\begin{array}{l}3,2 \pm \\
0,45\end{array}$ & $\begin{array}{l}3,9 \pm \\
0,46\end{array}$ & $\begin{array}{l}5,8 \pm \\
0,93\end{array}$ & $\begin{array}{l}100,0 \pm \\
0,00\end{array}$ & $\begin{array}{l}93,0 \pm \\
6,32\end{array}$ & $\begin{array}{l}74,3 \pm \\
5,16\end{array}$ & $\begin{array}{l}67,0 \pm \\
10,52\end{array}$ \\
\hline Red NIFI & $\begin{array}{l}4,4 \pm \\
0,13\end{array}$ & $\begin{array}{l}5,2 \pm \\
0,31\end{array}$ & $\begin{array}{l}5,7 \pm \\
0,33\end{array}$ & $\begin{array}{l}6,0 \pm \\
0,38\end{array}$ & $\begin{array}{l}3,0 \pm \\
0,24\end{array}$ & $\begin{array}{l}5,4 \pm \\
0,90\end{array}$ & $\begin{array}{l}7,8 \pm \\
2,09\end{array}$ & $\begin{array}{l}7,4 \pm \\
1,25\end{array}$ & $\begin{array}{l}100,0 \pm \\
0,00\end{array}$ & $\begin{array}{l}92,0 \pm \\
6,76\end{array}$ & $\begin{array}{l}88,0 \pm \\
7,30\end{array}$ & $\begin{array}{l}84,0 \pm \\
5,66\end{array}$ \\
\hline Merah & $\begin{array}{l}3,4 \pm \\
0,84\end{array}$ & $\begin{array}{l}4,5 \pm \\
0,44\end{array}$ & $\begin{array}{l}5,2 \pm \\
0,35\end{array}$ & $\begin{array}{l}5,4 \pm \\
0,36\end{array}$ & $\begin{array}{l}2,7 \pm \\
0,89\end{array}$ & $\begin{array}{l}3,8 \pm \\
1,01\end{array}$ & $\begin{array}{l}5,6 \pm \\
1,07\end{array}$ & $\begin{array}{l}6,1 \pm \\
0,77\end{array}$ & $\begin{array}{l}100,0 \pm \\
0,00\end{array}$ & $\begin{array}{l}70,0 \pm \\
14,34\end{array}$ & $\begin{array}{l}59 \pm \\
3,83\end{array}$ & $\begin{array}{l}59 \pm \\
3,83\end{array}$ \\
\hline Hitam & $\begin{array}{l}3,8 \pm \\
0,34\end{array}$ & $\begin{array}{l}4,4 \pm \\
0,13\end{array}$ & $\begin{array}{l}4,9 \pm \\
0,16\end{array}$ & $\begin{array}{l}5,3 \pm \\
0,21\end{array}$ & $\begin{array}{l}2,3 \pm \\
0,75\end{array}$ & $\begin{array}{l}3,9 \pm \\
0,48\end{array}$ & $\begin{array}{l}5,1 \pm \\
0,35\end{array}$ & $\begin{array}{l}5,8 \pm \\
0,49\end{array}$ & $\begin{array}{l}100,0 \pm \\
0,00\end{array}$ & $\begin{array}{l}79,0 \pm \\
11,06\end{array}$ & $\begin{array}{l}68,0 \pm \\
16,97\end{array}$ & $\begin{array}{l}61,0 \pm \\
7,57\end{array}$ \\
\hline
\end{tabular}

Tabel 2. Pertambahan Panjang, Bobot Tubuh, Sintasan dan Biomassa pada Lima Strain Ikan Nila setelah Pemeliharaan 30 Hari

\begin{tabular}{lcccc}
\hline Strain & $\begin{array}{l}\text { Pertambahan } \\
\text { Panjang }\end{array}$ & $\begin{array}{l}\text { Pertambahan } \\
\text { Bobot }\end{array}$ & Sintasan & $\begin{array}{l}\text { Pertambahan } \\
\text { biomassa }\end{array}$ \\
\hline BEST & $1,3 \pm 0,12$ & $4,0 \pm 0,34$ & $91,0 \pm 3,83$ & $89,1 \pm 14,86$ \\
Lokal Kuningan & $1,6 \pm 0,20$ & $3,4 \pm 0,58$ & $62,0 \pm 9,52$ & $42,7 \pm 5,91$ \\
Red NIFI & $1,6 \pm 0,36$ & $4,4 \pm 1,15$ & $84,0 \pm 5,66$ & $79,1 \pm 19,01$ \\
Merah & $2,0 \pm 0,76$ & $3,4 \pm 0,64$ & $59,0 \pm 3,83$ & $20,7 \pm 18,45$ \\
Hitam & $1,5 \pm 0,44$ & $3,5 \pm 0,73$ & $67,5 \pm 16,97$ & $31,58 \pm 27,37$ \\
\hline
\end{tabular}

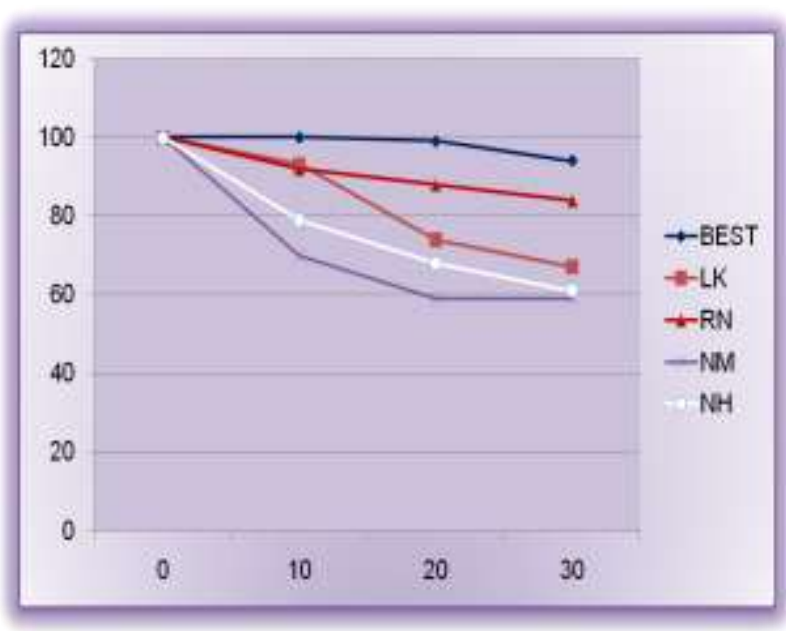

Gambar 1. Data Pengamatan Pertambahan Panjang Selama 30 Hari Pengamatan

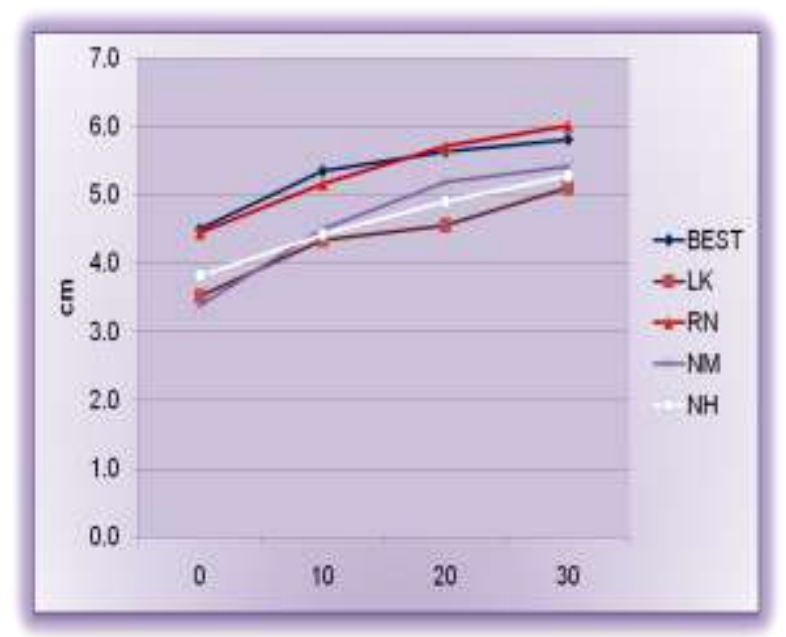

Gambar 2. Data Pengamatan Pertambahan Berat Selama 30 Hari Pengamatan 


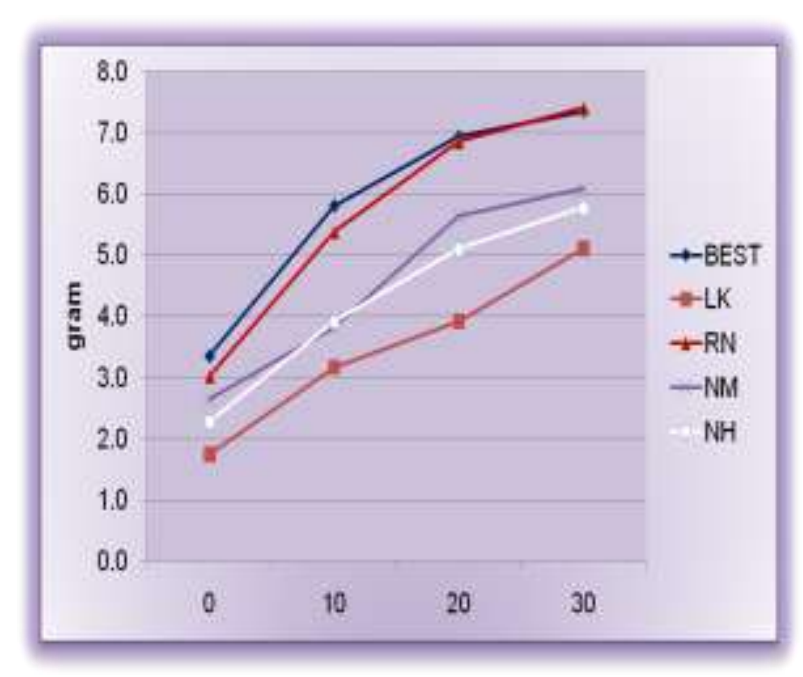

Gambar 3. Data Pengamatan Pertambahan Biomassa Selama 30 Hari Pengamatan

Berdasarkan data yang diperoleh, adanya indikasi dini pengaruh salinitas terhadap ketahanan lima strain yang diuji pada nilai sintasan dan pertumbuhan. Kemungkinan besar pengaruh tersebut akan menjadi lebih nyata dengan peningkatan lama waktu pengamatan dan ukuran yang diamati.

\section{KESIMPULAN}

Dari beberapa parameter yang diamati, hasil sementara menunjukkan ikan nila BEST lebih baik dalam sintasan dan pertambahan biomassa total dibandingkan dengan strain lainnya.

\section{UCAPAN TERIMA KASIH}

Penulis mengucapkan banyak terima kasih kepada Bapak Otong Zenal Arifin, Abdul Wakhid, Yosef Iskandar, Bei Abasari, Sirodiana atas saran dan masukkan serta bantuan teknis yang diberikan. Penelitian ini merupakan bagian Proyek Pengembangan Akuakultur yang dibiayai oleh DIPA 2009.

\section{DAFTAR PUSTAKA}

Arifin, O. Z., G. H. Huwoyon, dan R. Gustiano. 2009. Growth performance of the Black (BEST) and Red (Red NIFI) nile tilapia (Oreochromis niloticus) under separate rearing condition. Poster pada World
Ocean Conference, Manado, 11-15 Mei 2009.

Gustiano, R., Y. Suryanti dan A. Widiyati. 2005. Evaluasi pertumbuhan ikan nila (Oreochromis niloticus) di dua lingkungan yang berbeda. Aquacultura Indonesiana 6 : 79-84.

Huwoyon, G. H dan R. Gustiano. 2008. Uji keragaan ikan nila dan hitam dalam pemeliharaan bersama di kolam. Prosiding Seminar Nasional Perikanan 2008 (Editors : A. Permadi et al.), Jakarta. H : 225-228.

Kusdiarti, A. Widiyati dan R. Gustiano. 2008. Uji banding pertumbuhan biomasa ikan nila (Oreochromis niloticus) seleksi dan nonseleksi di waduk dan danau. Jurnal Iktiologi Indonesia 8: 21-24

Maluwa, A. O and H. Gjerde. 2006. Genetic parameters and genotype by environment interaction for body weight of Oreochromis shiranus. Aquaculture 259 : 47-55.

Matricia, T., A. J. Talbot and R. W. Doyle. 1989. Instantaneous growth rate of tilapia genotypes in undisturbed aquaculture systems I. "Red" and "Grey" morphs in Indonesia. Aquaculture 77 : 295-302.

Romana-Equia, M. R. R and R. W. Doyle. 1992. Genotype-environment interaction in the response of three strains of Nile Tilapia to poor nutrition. Aquaculture $108: 1-12$.

Ridha, M. T. 2008. Preliminary Observation on Salinity Tolerance of Three Sizes of the GIFT and Non-Improved Strains of the Nile Tilapia Oreochromis Niloticus European Journal of Scientific Research 24 (3) : 373377

Winarlin, R. Gustiano dan A. H. Kristanto. 2008. Uji Bandung pertumbuhan biomassan ikan nila (Oreochromis niloticus) seleksi dan non seleksi di kolam dan danau. Dalam Teknologi Perikanan Budidaya (Editors : H. Supriyadi et al.). Pusat Riset Perikanan Budidaya, Jakarta. $\quad \mathrm{H}: 21-2$. 